\title{
In vitro propagation of the endangered date palm (Phoenix dactylifera L.) cv. Ghazal: 2- Improvement of germination and development of embryos by silver nitrate and silver thiosulfate
}

\author{
*Mohamed Ismail Diab \\ Tissue Culture Unit, Genetic Resource Department, Ecology and Dry Land Agriculture Division, Desert \\ Research Center, EL-Matareya, Cairo, Egypt. \\ Corresponding Author: Mohamed Ismail Diab
}

\begin{abstract}
Date palm (Phoenix dactylifera L.) is one of the most importan tree crops in the deserts which is a tree high economic and commercial values. This study was performed to micro propagate of date palm $\mathrm{cv}$. Ghazal via somatic embryogenesis. Although, it was conducted to examine different concentration of silver nitrate (SN) and silver thiosulfate (STS) for their effect on somatic embryogenesis development of date palm. In this context, the obtained results indicated that, all silver treatments, whether nitrate or thiosulfate, had a positive effect. The highest number, length and growth value of somatic embryos formed are obtained from embryogenic celli cultured on Murashige and Skoog (MS) medium supplemented with $2.0 \mathrm{mg} / \mathrm{l} S \mathrm{~N}$ or $1.0 \mathrm{ml} / \mathrm{l}$ STS. Moreover, the results have shown that the $S N$ at $4.0 \mathrm{mg} / \mathrm{l}$ or $2.0 \mathrm{ml} / \mathrm{l}$ promoted the growth, proliferation, maturation and germination of somatic embryos of date palm. 80 and $82.2 \%$ of embryos had differentiated and germinated to plantlets when re-cultured on the same previously medium. While, the medium supplied with full strength $\mathrm{MS}$ medium with $1.0 \mathrm{mg} / \mathrm{l} I B A$ and $1.0 \mathrm{mg} / \mathrm{l} \mathrm{SN}$ or $0.5 \mathrm{ml} / \mathrm{l}$ STS showed superiority in the number of roots and their length in comparison with the other treatments. High frequencies of survival rates in greenhouse conditions were obtained after acclimatized and transferred to pots containing a mixture of peat moss and perlite at equal volume. Accordingly, these results suggest that adding silver nitrate or silver thiosulfate to the culture medium of date palm cv.Ghazal may be beneficial to improve the somatic embryogenesis growth performance and their developed for this cultivar.
\end{abstract}

Keywords: Date palm, somatic embryogenesis, silver nitrate, silver thiosulfate, ethylene inhibitors

\section{Introduction}

Micropropagation of date palm can be achieved through either somatic embryogenesis or direct organogenesis. Somatic embryogenesis is characterized by the development of somatic cell into an embryo with a bipolar structure, leading to shoot and root formation. It is considered as the most efficient regeneration process for date palm Micropropagation (Al- Khayri, 2011 a). Several studies were conducted to optimize somatic embryogenesis of date palm through the manipulation of culture medium ingredients including plant growth regulators (kurup et al.,2014), folic and biotin (Diab, 2015); casein hydrolysate (Al-Khayri 2011b); polyethylene glycol (AL-Khateeb and Ghazzawy, 2015) and silver nitrate as an inhibitor of ethylene (Al-Khayri and Al- Bahrany, 2004). The role of ethylene in plant tissue culture is not clear, although it can change the organogenic capacity of explants in vitro. Ethylene is a gaseous plant hormone involved in many aspects of plant life cycle such as seed germination, tissue differentiation, the formation of shoot and root primordial (Bleeker and Kende, 2000; Sridhar et al.,2011). Ethylene accumulation was found to be effected by tubes or jars closure method, gases exchange level and flaming. Ethylene accumulation cause culture growth inhibition (Mele et al., 1982).

Since silver ions inhibit the action of ethylene, both silver thiosulfate (STS) (Ag2S2O3) and silver nitrate ( $\mathrm{SN}$ ) (AgNO3) are effective in preventing ethylene action although the last is much more effective because it is reading translocated (Pierik, 1999). Kumar et al., 2009 indicated that silver ions were reducing the ability of receptors to bind ethylene with this observations water solubility and the absence of plant toxicity in an effective concentration led to its application in plant tissues. Silver nitrate (AgNO3) also induce growth, improved callus proliferation, embryogenic callus initiation and enhanced somatic embryogenesis (Adkins et al.,1993; Al- Khayri and AL-Bahrany, 2001 and 2004). Moreover, Silver nitrate was efficient plant regeneration from leaf of rapeseed (Brassica napus) (Akasaka et al., 2005). However, the use of silver thiosulfate has not yet been reported in date palm via indirect somatic embryogenesis. Therefore in this context, the aim of this study was to examine the effect of silver nitrate (SN) and silver thiosulfate (STS) at different concentrations on embryogenic callus growth and somatic embryogenesis of date palm cv. Ghazal. 


\section{Material And Methods}

Explant preparation, sterilization processes and embryo formation of date palm cv. Ghazal were implemented according to procedure described previously by Diab (2015). Surface sterilized explants were inoculated onto initiation culture medium consists of Murashige and Skoog (1962) basal medium (MS) supplemented with (per litre). $40 \mathrm{mg}$ adenine sulfate, $170 \mathrm{mg}$ sodium dihydrogen or the phosphate $\left(\mathrm{Na}_{2} \mathrm{PO}_{4}\right)$, $200 \mathrm{mg}$ glutamine, $0.5 \mathrm{mg}$ thiamine- $\mathrm{HCl}, 1 \mathrm{mg}$ nicotinic acid, $30 \mathrm{~g}$ sucrose and $2 \mathrm{~g}$ gelrite. This basal medium was used throughout the system with modification made according to each stage, the best medium for callus

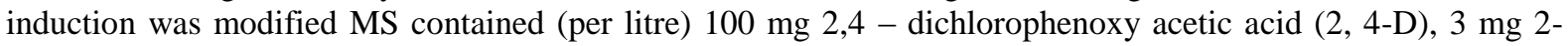
isopentenyladenine (2iP), $0.1 \mathrm{mg}$ folic acid (vitamin B9), $0.5 \mathrm{mg}$ biotin (vitamin $\mathrm{H}$ ) and $3 \mathrm{~g}$ activated charcoal (AC). This cultures were incubated at content temperature $27 \pm 2{ }^{\circ} \mathrm{C}$ under complete darkness for eight months and regular transfer to the same component fresh medium every 6 weeks. At the end of this period, the highest value of embryogenic callus formed when was cultured on modified MS medium supplemented with (per litre) 10mg. 2,4-D, 3mg 2iP, $0.5 \mathrm{mg}$ folic acid and $1.0 \mathrm{mg}$ biotin. The embryogenic calli were formed and then transferred to MS medium containing (per litre) $0.1 \mathrm{mg}$ naphthalene acetic acid (NAA), $0.5 \mathrm{mg}$ folic acid and $1.0 \mathrm{mg}$ biotin to obtained somatic embryos formation. To test the effect of silver nitrate (SN) and silver thiosulfate (STS) on somatic embryogenesis growth and development. For embryos formation, embryogenic callus $\left(0.3 \mathrm{~g}\right.$ ) was cultured on MS medium (the same previously medium composition) containing $\mathrm{AgNO}_{3}$ at 0.0 , $0.25,0.5,1.0,2.0,4.0$ and $8.0 \mathrm{mg} / 1$ or $\mathrm{Ag}_{2} \mathrm{~S}_{2} \mathrm{O}_{3}$ at $0.0,0.25,0.5,1.5,2.0,4.0$ and $8.0 \mathrm{ml} / 1$. Each treatment consisted of three replicates and each one contained three jars. All cultures were incubated in a growth room at $27 \pm 2^{\circ} \mathrm{C}$ under 16-hours daily exposure to low light intensity of photoperiod $\left(13.5 \mu \mathrm{mol} \mathrm{m}^{-2} \mathrm{~s}^{-1)}\right.$ illumination. After 6 weeks, average number of somatic embryo and their length and growth values of embryos were recorded. For maturation and proliferation, a small cluster containing 3-4 embryos inoculated in the same medium composition and incubated in a growth room at $27 \pm 2^{\circ} \mathrm{C}$ with 16 -hours photoperiod $\left(40.5 \mu \mathrm{mol} \mathrm{m} \mathrm{m}^{-2} \mathrm{~s}^{-1}\right)$ under cool white florescent lamps. Average number, length and growth value (GV) of embryos were recorded.

$$
(G V)=\frac{\text { Final fresh weight }- \text { Intial fresh weight }}{\text { Initial fresh weight }}(\text { Ziv, 1992) }
$$

After 12 weeks of culturing, for germination of somatic embryos, the percentage of the germinated embryos in response to $\mathrm{AgNO}_{3}$ or $\mathrm{Ag}_{2} \mathrm{~S}_{2} \mathrm{O}_{3}$ at different concentrations $0.0,0.25,0.5,1.0,2.0,4.0$ and $8.0 \mathrm{mg} / \mathrm{l}$ or $\mathrm{ml} / \mathrm{l}$, respectively were calculated based on the total embryos regenerated in each treatment.

For rooting stage, an individual shoot of $\mathrm{cv}$. Ghazal, 7-9 cm in length with 2-3 leaves were cultured on full-strength MS medium supplemented with the previously mentioned concentrations of $\mathrm{AgNO}_{3}$ (SN) or $\mathrm{Ag}_{2} \mathrm{~S}_{2} \mathrm{O}_{3}$ (STS) addition to $1.0 \mathrm{mg} / \mathrm{l}$ NAA. All culture tubes were incubated at $27 \pm 2^{\circ} \mathrm{C}$ for 8 weeks ( 4 weeks intervals) in growth room under a 16 hours illumination of $40.5 \mu \mathrm{mol} \mathrm{m}^{-2} \mathrm{~s}^{-1}$. Nine glass tubes (replicates) were used for each treatment. After eight weeks, average number of roots /shoot and average root length $(\mathrm{cm})$ growth were recorded. Plantlets resulted from the rooting previous stage were acclimatized on pots containing a mixture of peat moss and perlit at equal volume.

\section{Experimental Design and Statistical Analysis of Data:}

The experiments were subjected to completely randomized design. Analysis of variance (ANOVA) and Duncan's multiple range test (Duncan, 1955), as modified by Snedecor and Cochran (1982), were performed to analyze the obtained data. The differences among averages of the recorded parameters for all treatments were tested for significance at $5 \%$ level, averages followed by the same latter are not significantly different at $P<0.05$.

\section{Results And Discussion}

Effect of different concentrations of silver nitrate (SN) and silver thiosulfate (STS) on somatic embryo formation (the number, length and growth value of embryos) of date palm cv. Ghazal after 6 weeks from culture is presented in Tables 1 and 2. Embryogenic callus (0.3g), Fig.1, which produced from early stages of growth, were transferred onto fresh medium supplemented with $0.1 \mathrm{mg} / \mathrm{l} \mathrm{NAA}$ continued to differentiate embryogenic callus, develop somatic embryos and its formation.
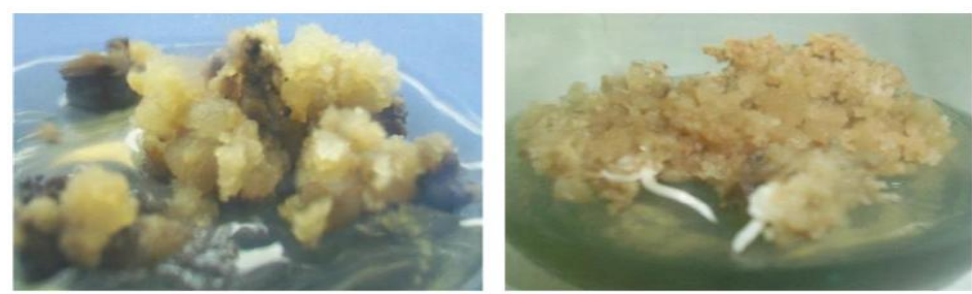

Figure1. Somatic embryogenic callus from shoot tip explants of date palm cv. Ghazal. 
Data in Table 1 and Fig.2B revealed that increase in the concentration of SN gradually to $2.0 \mathrm{mg} / \mathrm{l}$ led to a marked increase in the number and length of the embryo compared to the control treatment. In this respect, the embryos number gave the highest significant value (4.17 embryos/culture) and highest average length of embryos $(1.94 \mathrm{~cm})$ on MS medium supplemented with $2.0 \mathrm{mg} / \mathrm{l} \mathrm{SN}$ compared with the other treatments. While, the lowest number of embryos was recorded on MS medium containing $8.0 \mathrm{mg} / 1 \mathrm{SN}(0.67$ embryos/culture $)$ and the lowest without significant average embryos length were 0.85 and $0.88 \mathrm{~cm}$ on the media containing 4.0 or 8.0 $\mathrm{mg} / \mathrm{S} \mathrm{SN}$, respectively.

Table (1): Effect of different concentrations of $\mathrm{AgNO}_{3}(\mathrm{SN})+0.1 \mathrm{mg} / \mathrm{l} \mathrm{NAA}$ on embryogenic callus differentiation and development of date palm cv. Ghazal, cultured in vitro after 6 weeks

\begin{tabular}{|c|c|c|c|}
\hline $\begin{array}{c}\text { AgNO } \mathbf{3}(\mathbf{S N}) \\
\text { Concentrations } \\
(\mathbf{m g} / \mathbf{l})\end{array}$ & $\begin{array}{c}\text { Average } \\
\text { number of } \\
\text { embryos/ culture }\end{array}$ & $\begin{array}{c}\text { Average length of } \\
\text { embryo/ culture } \\
(\mathbf{c m})\end{array}$ & $\begin{array}{c}\text { Growth value } \\
(\mathbf{G V})\end{array}$ \\
\hline 0.0 & $2.33 \mathrm{e}$ & $1.00 \mathrm{e}$ & $1.66 \mathrm{e}$ \\
\hline 0.25 & $3.17 \mathrm{~d}$ & $1.30 \mathrm{~d}$ & $1.83 \mathrm{~d}$ \\
\hline 0.50 & $3.50 \mathrm{c}$ & $1.42 \mathrm{c}$ & $2.20 \mathrm{c}$ \\
\hline 1.0 & $3.83 \mathrm{~b}$ & $1.67 \mathrm{~b}$ & $2.80 \mathrm{~b}$ \\
\hline 2.0 & $4.17 \mathrm{a}$ & $1.94 \mathrm{a}$ & $3.81 \mathrm{a}$ \\
\hline 4.0 & $1.17 \mathrm{f}$ & $0.85 \mathrm{f}$ & $1.12 \mathrm{f}$ \\
\hline
\end{tabular}

Means within a column followed by the same letters are not significantly different at $p<0.05$

Data presented in Table (1) also reveal the effect of $0.1 \mathrm{mg} / \mathrm{l}$ NAA and different concentrations of SN on growth value $(\mathrm{GV})$ of differentiated somatic embryos of date palm. The highest growth value was occurred in response to $2.0 \mathrm{mg} / \mathrm{l} \mathrm{SN}$ (3.81), followed by $1.0 \mathrm{mg} / \mathrm{l} \mathrm{SN}$, where $\mathrm{GV}$ was 2.80 compared to the control (1.66). Whereas, the high concentrations $(4.0$ or $8.0 \mathrm{mg} / \mathrm{l}) \mathrm{SN}$ have not a significant differences among of them and were less effective than SN treatments (1.12 and 1.16), respectively.

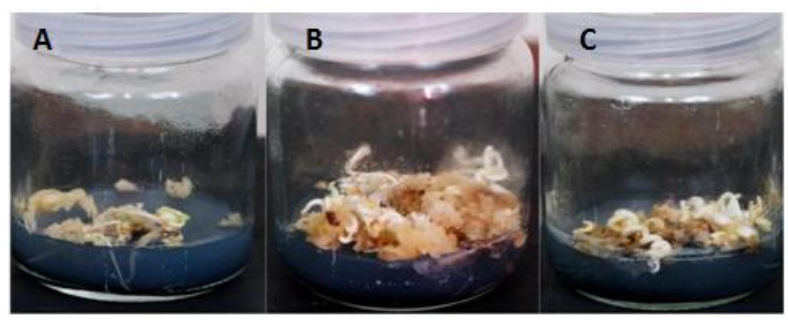

Figure 2. Somatic embryos formation of date palm cv. Ghazal.
A. Control treatment.
B. MS medium supplemented with $2.0 \mathrm{mg} / \mathrm{l} \mathrm{SN}$.
C. MS medium supplemented with $1.0 \mathrm{ml} / 1 \mathrm{STS}$.

Although, data in Table 2 and Fig. 2C illustrated the similar trend in the results regarding the effect of STS at different concentrations and $0.1 \mathrm{mg} / 1 \mathrm{NAA}$ on each of the number, length and growth value of embryos. MS medium supplemented with $1.0 \mathrm{mg} / \mathrm{l} \mathrm{STS}$ was recorded the best result compared with other concentrations, where it was 4.33 embryos/ culture.

Table (2): Effect of different concentrations of $\mathrm{Ag}_{2} \mathrm{~S}_{2} \mathrm{O}_{3}$ (STS) $+0.1 \mathrm{mg} / \mathrm{l} \mathrm{NAA}$ on embryogenic callus differentiation and development of date palm cv. Ghazal, cultured in vitro after 6 weeks

\begin{tabular}{|c|c|c|c|}
\hline $\begin{array}{c}\mathbf{A g}_{2} \mathbf{S}_{\mathbf{2}} \mathbf{O}_{\mathbf{3}}(\mathbf{S T S}) \\
\begin{array}{c}\text { Concentrations } \\
(\mathbf{m l} / \mathbf{l})\end{array}\end{array}$ & $\begin{array}{c}\text { Average } \\
\text { number of } \\
\text { embryos/ culture }\end{array}$ & $\begin{array}{c}\text { Average length of } \\
\text { embryo/ culture } \\
(\mathbf{c m})\end{array}$ & $\begin{array}{c}\text { Growth value } \\
(\mathbf{G V})\end{array}$ \\
\hline 0.0 & $2.33 \mathrm{~d}$ & $1.13 \mathrm{e}$ & $1.73 \mathrm{f}$ \\
\hline 0.25 & $2.83 \mathrm{c}$ & $1.50 \mathrm{c}$ & $1.93 \mathrm{~d}$ \\
\hline 0.5 & $3.67 \mathrm{~b}$ & $1.75 \mathrm{~b}$ & $2.33 \mathrm{c}$ \\
\hline 1.0 & $4.33 \mathrm{a}$ & $1.97 \mathrm{a}$ & $3.86 \mathrm{a}$ \\
\hline 2.0 & $2.37 \mathrm{~d}$ & $1.32 \mathrm{~d}$ & $2.84 \mathrm{~b}$ \\
\hline 4.0 & $1.50 \mathrm{e}$ & $1.00 \mathrm{f}$ & $1.83 \mathrm{e}$ \\
\hline 8.0 & $1.17 \mathrm{f}$ & $0.96 \mathrm{f}$ & $1.88 \mathrm{de}$ \\
\hline
\end{tabular}

Means within a column followed by the same letters are not significantly different at $\mathrm{p}<0.05$

As well as, the average length of embryos was affected also by STS concentration, it ranged from 1.32 to $1.97 \mathrm{~cm}$ at concentrations lower than $4.0 \mathrm{ml} / \mathrm{l}$ and the control treatment, where it was $1.13 \mathrm{~cm}$ increasing STS concentration to $8.0 \mathrm{ml} / \mathrm{l}$ decreased the average length. So, the MS medium supplemented with $1.0 \mathrm{ml} / 1 \mathrm{STS}$ was the best greatest activity medium to improve the average length of embryo, which reached $1.97 \mathrm{~cm}$ and caused a significant increase in the GV compared with control treatment (1.73).

Finally, from previously data in Tables (1 and 2), it could be concluded that the MS medium supplemented with $0.1 \mathrm{mg} / 1 \mathrm{NAA}$ and $2.0 \mathrm{mg} / \mathrm{l}(\mathrm{SN})$ or $1.0 \mathrm{ml} / \mathrm{l}$ (STS) were suitable, more effective for embryos 
formation (differentiation) and which gave the best results for embryos number (4.17 and 4.33 embryos/ culture) with average embryos length $(1.94$ and $1.97 \mathrm{~cm})$ and $\mathrm{GV}$ (3.81 and 3.86) of date palm cv.Ghazal, respectively. These results are in agreement with those found by Songstad et al., (1988) have shown that the plantlets number of maize plant produced from embryogenic callus increased in response to increasing the concentration of SN. Similarly, Roustan et al., (1990) have shown that SN increased the number of carrot somatic embryos. In a study on date palm, Al-Khayri and AL-Bahrany (2001) also reported that embryogenesis increased in response to low level of SN but at higher concentrations, the number of embryos decreased. Conversely, in another study on the coffee, Hatanaka et al., (1995) have shown that embryo formation was completely absent in response to the addition of SN. This suggests that the promotive action of SN is related to the plant species. The above results indicated that SN or STS promote and growth of date palm in vitro. This might be due to the role of $\mathrm{Ag}^{+}$ ions which overcome the action and metabolism of ethylene (Beyer, 1979). Ethylene is known to inhibit and sometime stimulate in vitro growth and morphogenesis depending upon the species and culture stage (Kumar et al., 1998). $\mathrm{Ag}^{+}$ions play also major role in influencing somatic embryogenesis, shoot formation and efficient root formation (Bais et al.,2001).Similar results have also been reported by Al-Khayri and Al-Bahrany (2001), they found that SN promoted callus proliferation, increased embryogenic callus weight in the absence of cytokinin, enhanced the formation and elongation of somatic embryos of date palm. They added, the action of SN was clearly modified by the addition of $2 \mathrm{iP}$. The number of resultant embryos was the highest and caused maximum elongation on $25 \mu \mathrm{M}(4.3 \mathrm{mg} / \mathrm{l}) \mathrm{SN}$ in combination with $0.5 \mu \mathrm{M}(0.1 \mathrm{mg} / \mathrm{l}) 2 \mathrm{iP}$.

Effect of different concentrations of SN and STS on embryos growth and development (proliferation of white embryos) of date palm cv. Ghazal after 12 weeks from culture is presented in Tables (3 and 4). From data presented in Table 3 and Fig. 3B, it is clear that the increasing of SN concentration until $4.0 \mathrm{mg} / \mathrm{l}$, the average number and length of embryos increased.

Table (3): Effect of different concentrations of $\mathrm{AgNo}_{3}(\mathrm{SN})+0.1 \mathrm{mg} / \mathrm{l} \mathrm{NAA}$ on growth and development of embryos (Proliferation and maturation) of date palm cv. Ghazal cultured in vitro after 12 weeks

\begin{tabular}{|c|c|c|c|}
\hline $\begin{array}{c}\text { AgNO } \\
\text { Concentrations } \\
(\mathbf{m g} / \mathbf{l})\end{array}$ & $\begin{array}{c}\text { Average } \\
\text { number of } \\
\text { embryos/ culture }\end{array}$ & $\begin{array}{c}\text { Average length } \\
\text { of embryo/culture } \\
\text { (cm) }\end{array}$ & $\begin{array}{c}\text { Growth value } \\
(\mathbf{G V})\end{array}$ \\
\hline 0.0 & $3.44 \mathrm{f}$ & $1.93 \mathrm{f}$ & $2.06 \mathrm{e}$ \\
\hline 0.25 & $5.67 \mathrm{e}$ & $2.35 \mathrm{e}$ & $2.20 \mathrm{~d}$ \\
\hline 0.50 & $6.56 \mathrm{~d}$ & $2.42 \mathrm{~d}$ & $2.40 \mathrm{c}$ \\
\hline 1.0 & $7.33 \mathrm{c}$ & $5.46 \mathrm{~b}$ & $4.51 \mathrm{~b}$ \\
\hline 2.0 & $7.89 \mathrm{~b}$ & $4.67 \mathrm{c}$ & $4.55 \mathrm{~b}$ \\
\hline 4.0 & $8.44 \mathrm{a}$ & $5.53 \mathrm{a}$ & $4.86 \mathrm{a}$ \\
\hline 8.0 & $3.17 \mathrm{~g}$ & $1.42 \mathrm{~g}$ & $1.83 \mathrm{f}$ \\
\hline
\end{tabular}

Means within a column followed by the same letters are not significantly different at $\mathbf{p}<0.05$

The highest significant number $(8.44$ embryos) and highest average length of embryos $(5.35 \mathrm{~cm})$ with the highest GV (4.86) were obtained on $4.0 \mathrm{mg} / \mathrm{l} \mathrm{SN}$, as compared to control treatment, where it was 3.44 embryos with the shortest embryo (with a mean length of $1.93 \mathrm{~cm}$ ). While, significant number, length and GV were recorded on $8.0 \mathrm{mg} / \mathrm{l} \mathrm{SN}$ which gave 3.17 embryos with average length $1.42 \mathrm{~cm}$ and low of GV(1.83).

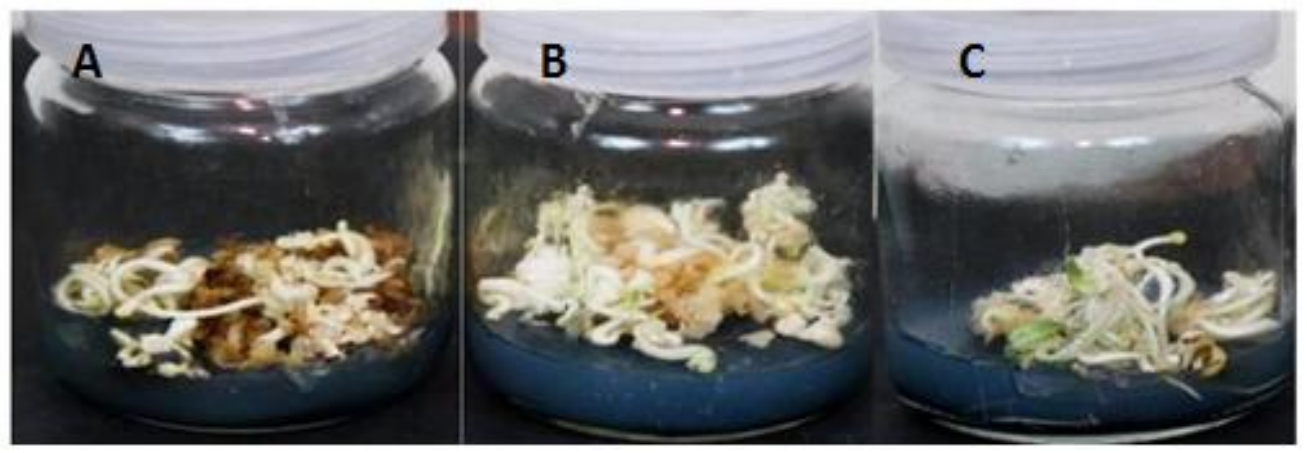

Figure 3. Somatic embryos growth and development (embryos proliferation and maturation) of date palm cv Ghazal.

A. Control treatment.

B. MS medium supplemented with $4.0 \mathrm{mg} / \mathrm{l} \mathrm{SN}$.

C. MS medium supplemented with $2.0 \mathrm{ml} / 1 \mathrm{STS}$.

Other treatments were more effective than control treatment, where the number and average length of embryos ranged from 5.67 to 7.89 embryos and from 2.35 to $5.46 \mathrm{~cm}$, respectively. Also, data presented in Table 4 show the same trend in the results. 
In vitro propagation of the endangered date palm (Phoenix dactylifera L.) cv. Ghazal: 2-

Table (4): Effect of different concentrations of $\mathrm{Ag}_{2} \mathrm{~S}_{2} \mathrm{O}_{3}+0.1 \mathrm{mg} / \mathrm{l} \mathrm{NAA}$ on growth and development of embryos (proliferation and maturation) of date palm cv. Ghazal, cultured in vitro after 12 weeks

\begin{tabular}{|c|c|c|c|}
\hline $\begin{array}{c}\mathbf{A g}_{2} \mathbf{S}_{\mathbf{2}} \mathbf{O}_{3} \text { (STS) } \\
\text { concentrations } \\
(\mathbf{m l} / \mathbf{l})\end{array}$ & $\begin{array}{c}\text { Average } \\
\text { number of } \\
\text { embryos/ culture }\end{array}$ & $\begin{array}{c}\text { Average length of } \\
\text { embryo/ culture } \\
(\mathbf{c m})\end{array}$ & $\begin{array}{c}\text { Growth } \\
\text { value } \\
(\mathbf{G V})\end{array}$ \\
\hline 0.0 & $3.44 \mathrm{~g}$ & $1.93 \mathrm{f}$ & $2.19 \mathrm{f}$ \\
\hline 0.25 & $6.89 \mathrm{~d}$ & $2.36 \mathrm{e}$ & $2.85 \mathrm{e}$ \\
\hline 0.5 & $7.67 \mathrm{c}$ & $3.70 \mathrm{c}$ & $2.94 \mathrm{~d}$ \\
\hline 1.0 & $8.22 \mathrm{~b}$ & $4.92 \mathrm{~b}$ & $3.08 \mathrm{c}$ \\
\hline 2.0 & $8.78 \mathrm{a}$ & $5.84 \mathrm{a}$ & $4.52 \mathrm{~b}$ \\
\hline 4.0 & $6.11 \mathrm{e}$ & $3.00 \mathrm{~d}$ & $5.43 \mathrm{a}$ \\
\hline 8.0 & $4.78 \mathrm{f}$ & $1.97 \mathrm{f}$ & $4.48 \mathrm{~b}$ \\
\hline
\end{tabular}

Means within a column followed by the same letters are not significantly different at $\mathbf{p}<0.05$

The addition of STS enhanced embryogenesis, the number of consequent embryos increased in response to increasing STS concentration. The highest significant number and average length of embryos $(8.78$ embryos and $5.84 \mathrm{~cm}$ ) were recorded on medium supplemented with $2.0 \mathrm{ml} / 1 \mathrm{STS}$ (Fig.3C). While, the lowest significant number of embryos was recorded on control treatment which gave 3.44 embryos with average length of $1.93 \mathrm{~cm}$. Other treatments were produced intermediate significant values between the highest and lowest values. Regarding the growth value, higher significant of GV was obtained on $4.0 \mathrm{ml} / \mathrm{l} \mathrm{STS}$ (5.43) followed by 2.0 and $8.0 \mathrm{ml} / \mathrm{l}$ STS where GV were 4.52 and 4.48 , respectively, without significant difference in between. While, the lowest significant GV of embryos was recorded on control treatment which gave value of 2.19. Other treatments (from 0.25 to $1.0 \mathrm{mg} / \mathrm{l} \mathrm{STS}$ ) given intermediate values and it ranged from 2.85 to 3.08 .

Generally, from the previous data in Tables, (3 and 4) it could be concluded that, the medium with SN at $4.0 \mathrm{mg} / \mathrm{l}$ or STS at $2.0 \mathrm{ml} / \mathrm{l}$ improved the number, length and GV of embryos. AgNO3 is a potent inhibitor of ethylene action and it is considered to suppress shoot organogenesis in vitro. Zhao and Davis (2005) considered that the increased of shoot regeneration frequency by $\mathrm{SN}$ is caused by the interruption of an ethylene signal transduction pathway. The positive effect of SN on shoot regeneration has already been reported for a number of plant including black cherry (Lui and Pijut 2008); French plum cultivar (Petri and Scorza, 2010). sesame (Abdellatef et al., 2010); tomato (Osman and Khalafalla, 2010); Potato (Sandra and Maira, 2013) and Cherry rootstocks (Sarropoulou et al., 2016). Moreover, increase in shoot regeneration and leaf chlorophyll content when SN was added to banana culture medium. The highest number of shoots per explant, shoot length and leaf surface area were obtained when medium was supplemented with $10 \mathrm{mg} / \mathrm{l} \mathrm{SN}$ (Tamimi, 2015). In the same trend, Bekheet (2013) found that supplementation of culture medium with SN combined with $2 \mathrm{iP}$ enhanced shoot bud multiplication of date palm cv. Zaghlool presented as number and length. The concentration of $5 \mathrm{mg} / \mathrm{l}$ $\mathrm{SN}$ was the most effective in the induction of multiple shoot buds compared to other concentrations. Whereas, Bader and Khierallah (2009) found that the addition of STS at $90 \mathrm{M}$ to culture medium gave the best result for adventitious bud formation and highest average of shoots number for cvs. Barhi and Maktom. In the same direction, Panathula et al., (2014) reported that silver thiosulphate enhanced in vitro regeneration of Centella asiatica L. when added to culture medium. Somatic embryos germination was observed in all examined silver treatments either STS or SN and the germination percent varied from 51.1 to $82.2 \%$ (Table 5).

Table (5): Effect of different concentrations of $\mathrm{AgNO}_{3}(\mathrm{SN})$ and $\mathrm{Ag}_{2} \mathrm{~S}_{2} \mathrm{O}_{3}$ (STS) on germination of somatic embryos percentage of date palm cv. Ghazal

\begin{tabular}{|c|c|}
\hline $\begin{array}{c}\text { AgNO }_{3}(\mathbf{S N}) \\
\text { concentrations (mg/l) }\end{array}$ & $\begin{array}{c}\text { Embryo germination } \\
\text { percentage (\%) }\end{array}$ \\
\hline 0.0 & $51.1 \mathrm{~g}$ \\
\hline 0.25 & $60.0 \mathrm{e}$ \\
\hline 0.5 & $64.4 \mathrm{~d}$ \\
\hline 1.0 & $66.7 \mathrm{c}$ \\
\hline 2.0 & $75.6 \mathrm{~b}$ \\
\hline 4.0 & $80.0 \mathrm{a}$ \\
\hline 8.0 & $53.3 \mathrm{f}$ \\
\hline Ag2S2O3 (STS) & \\
\hline concentrations (ml/l) & $51.1 \mathrm{~g}$ \\
\hline 0.0 & $64.4 \mathrm{~d}$ \\
\hline 0.25 & $68.9 \mathrm{c}$ \\
\hline 0.5 & $77.8 \mathrm{~b}$ \\
\hline 1.0 & $82.2 \mathrm{a}$ \\
\hline 2.0 & $62.2 \mathrm{e}$ \\
\hline 4.0 & $55.6 \mathrm{f}$ \\
\hline 8.0 & $6 \mathrm{dat}<0.05$ \\
\hline
\end{tabular}

Means within a column followed by the same letters are not significantly different at $p<0.05$ 
The culture medium supplemented with SN at $2.0 \mathrm{mg} / \mathrm{l}$ and STS at $4.0 \mathrm{ml} / \mathrm{l}$ gave the highest percentages of somatic embryos germination (80 and 82.2\%), respectively, compared to the other treatments (Fig. 4).

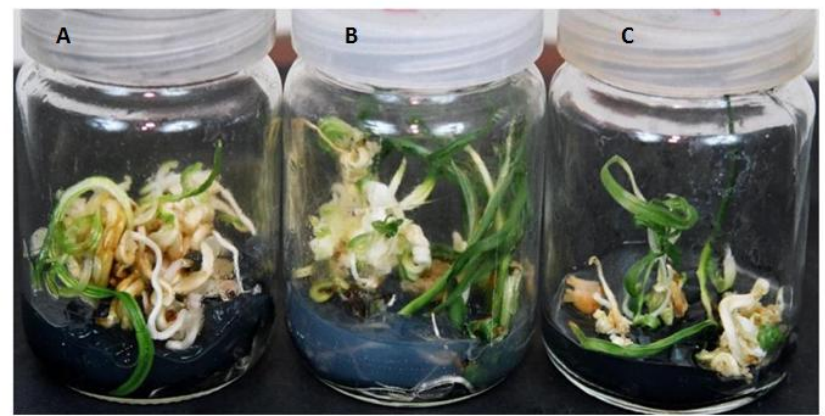

Figure 4. Somatic embryos germination of date palm cv. Ghazal (enhanced germination percentage of embryos with both silver compounants).

Nevertheless, the control treatment gave the lowest percentage of germination $(51.1 \%)$. The embryo germination percentage increased linearly with increasing concentration for both silver until treatment with 4.0 $\mathrm{mg} / 1 \mathrm{SN}$ or $2.0 \mathrm{ml} / \mathrm{l} \mathrm{STS}$. Except for treatment with SN at $8.0 \mathrm{mg} / \mathrm{l}$ and STS at $4.0 \mathrm{or} 8.0 \mathrm{ml} / 1$ were a significant decrease of embryo germination. Whereas, the concentration above $8 \mathrm{mg} / \mathrm{l} \mathrm{SN}$ or $8.0 \mathrm{ml} / \mathrm{l} \mathrm{STS}$ gave negative results and eventually embryos died (data not shown). At same time, the matured embryos were produced a shoots dark green color (Fig.5) and few thin and weak roots after four weeks. This observed is in agreement with these obtained by Hassanen and Gabr (2013) who observed that leaves of prcan became dark green color add NS to MS medium. Removal of germinating embryos and the next experiment allowed fast growth of individual embryos and their development into whole plantlets $(7-9 \mathrm{~cm}$ in length) cultured in vitro after four weeks, where transferred to rooting stage.

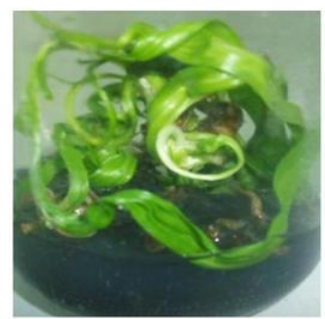

Figure 5. Matured somatic embryos showing shoots dark green color of date palm cv. Ghazal.

To improve in vitro rooting, data presented in Tables (6 and 7) clearly show the Effect of different concentrations of SN and STS on the in vitro rooting for shoots of date palm cv. Ghazal after four weeks. The response was more pronounced with rooting percentage, where all treatments resulted in $100 \%$ rooting (data not shown). Data in Table 6 show the effect of seven concentrations of SN added to MS rooting medium supplemented with $1.0 \mathrm{mg} / \mathrm{l} \mathrm{NAA}$ on rooting measurements (average number of roots/ shoot and average root length). Data clearly show that $\mathrm{SN}$ at $1.0 \mathrm{mg} / \mathrm{l}$ gave the highest significant average roots number (5.78) with significant average length $(5.03 \mathrm{~cm})$ (Fig. 6B), followed by 2.0 and $0.5 \mathrm{mg} / \mathrm{l} \mathrm{SN}$ (4.44 and 3.78 roots/ shoot) and (4.33 and $3.89 \mathrm{~cm}$ length of roots), respectively with in significant difference in between.

Table (6): Effect of different concentrations of $\mathrm{AgNO}_{3}(\mathrm{SN})$ on average number and length of roots/ shoot of date palm cv. Ghazal

\begin{tabular}{|c|c|c|}
\hline $\begin{array}{c}\mathbf{A g N O}_{3}(\mathbf{S N}) \text { concentrations } \\
\text { (mg/l) }\end{array}$ & $\begin{array}{c}\text { Average } \\
\text { number of roots/ shoot }\end{array}$ & $\begin{array}{c}\text { Average length of root } \\
(\mathbf{c m})\end{array}$ \\
\hline 0.0 & $1.67 \mathrm{~g}$ & $1.00 \mathrm{~g}$ \\
\hline 0.25 & $1.78 \mathrm{f}$ & $2.78 \mathrm{~d}$ \\
\hline 0.50 & $3.78 \mathrm{c}$ & $3.89 \mathrm{c}$ \\
\hline 1.0 & $5.78 \mathrm{a}$ & $5.03 \mathrm{a}$ \\
\hline 2.0 & $4.44 \mathrm{~b}$ & $4.33 \mathrm{~b}$ \\
\hline 4.0 & $2.11 \mathrm{~d}$ & $1.64 \mathrm{f}$ \\
\hline 8.0 & $1.89 \mathrm{e}$ & $1.33 \mathrm{e}$ \\
\hline
\end{tabular}

Means within a column followed by the same letters are not significantly different at $p<0.05$

While, the lowest significant values were observed by using medium without SN (control treatment) (1.67 roots/ shoot and $1.0 \mathrm{~cm}$ length). Other treatments were efficient than control treatment, where the number of 
roots ranged from 1.78 to 4.44 roots/ shoot and their length ranged from 1.33 to $4.33 \mathrm{~cm}$ with significant difference in between. Roots number and length were increased by increasing the level of SN until $1.0 \mathrm{mg} / \mathrm{l}$.
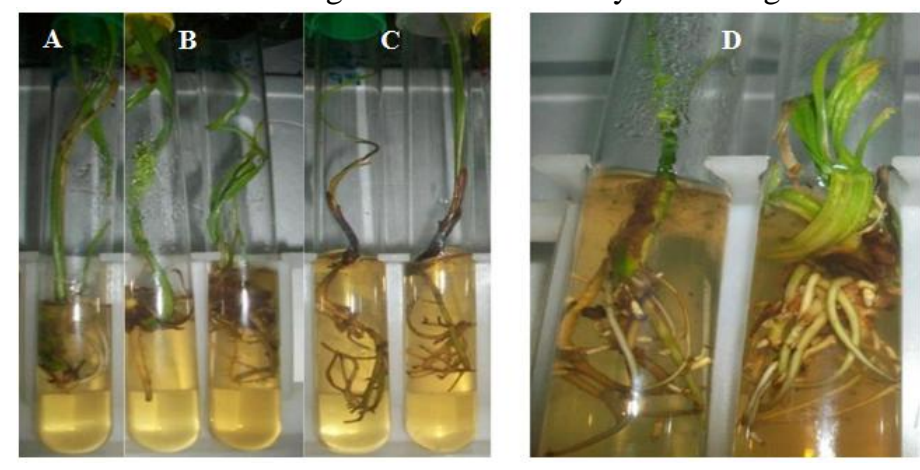

Figure 6. In vitro improved rooting (number and length of roots) of date palm cv. Ghazal.
A. Control treatment.
B. $\mathrm{MS}$ medium $+1.0 \mathrm{mg} / \mathrm{l} \mathrm{NAA}+1.0 \mathrm{mg} / \mathrm{l} \mathrm{SN}$.
C. $\mathrm{MS}$ medium $+1.0 \mathrm{mg} / \mathrm{l} \mathrm{NAA}+0.5 \mathrm{ml} / \mathrm{l} \mathrm{STS}$.
D. Shoots are vigor, dark green color and thickness of roots with increasing STS concentrations.

Where they were $1.78,3.78$ and 5.78 roots/ shoot with lengths $2.78,3.89$ and $5.03 \mathrm{~cm}$ at $0.25,0.50$ and $1.0 \mathrm{mg} / \mathrm{l} \mathrm{SN}$ respectively, then were decreased by increasing SN concentration. In the same direction, the data tabulated in Table 7 revealed that, all investigated STS levels add to MS rooting parameters number and length of roots over control treatment. However, MS medium containing $0.5 \mathrm{ml} / 1 \mathrm{STS}$ was statistically the superior and the best medium, since the greatest number $(6.22$ roots/ shoot $)$ and the tallest of root $(4.83 \mathrm{~cm})($ Fig. $6 \mathrm{C})$.

Table (7): Effect of different concentrations of $\mathrm{Ag}_{2} \mathrm{~S}_{2} \mathrm{O}_{3}$ (STS) on average number and length of roots/ shoot of date palm cv. Ghazal

\begin{tabular}{|c|c|c|}
\hline $\begin{array}{c}\mathbf{A g}_{2} \mathbf{S}_{2} \mathbf{O}_{\mathbf{3}}(\mathbf{S T S}) \\
\text { concentrations (ml/l) }\end{array}$ & $\begin{array}{c}\text { Average number of } \\
\text { roots/ shoot }\end{array}$ & $\begin{array}{c}\text { Average length } \\
\text { of root (cm) }\end{array}$ \\
\hline 0.0 & $1.67 \mathrm{~g}$ & $0.92 \mathrm{f}$ \\
\hline 0.25 & $2.44 \mathrm{e}$ & $1.49 \mathrm{e}$ \\
\hline 0.50 & $6.22 \mathrm{a}$ & $4.83 \mathrm{a}$ \\
\hline 1.0 & $5.11 \mathrm{~b}$ & $3.81 \mathrm{~b}$ \\
\hline 2.0 & $4.33 \mathrm{c}$ & $3.33 \mathrm{c}$ \\
\hline 4.0 & $3.56 \mathrm{~d}$ & $2.89 \mathrm{~d}$ \\
\hline 8.0 & $2.00 \mathrm{f}$ & $1.54 \mathrm{e}$ \\
\hline
\end{tabular}

Means within a column followed by the same letters are not significantly different at $p<0.05$.

While, the lowest significant values (number and length of roots) were observed by using medium without STS (control treatment) (1.67 roots/ shoot and their average length of $0.92 \mathrm{~cm}$ ). Increasing STS concentration from 0.5 to $8.0 \mathrm{ml} / 1$ decreased gradually average root number and their average length. In addition, from the visual observation, shoot color became dark green and more vigor and thickness of roots with increasing SN and STS concentrations (Fig. 6D).

Generally, it could be concluded that providing MS rooting medium with SN or STS improved rooting measurements (number of roots/ shoot and their average length) of date palm cv. Ghazal. Plantlets regenerated by culturing shootlets proliferated from the indirectly formed somatic embryos. However, the concentration 1.0 $\mathrm{mg} / \mathrm{l} \mathrm{SN}$ and $0.5 \mathrm{ml} / 1 \mathrm{STS}$ were statistically the superior.

These results are in agreement with those obtained by Hassanen and Gabr (2013) who reported that, $\mathrm{SN}$ at $1.5 \mathrm{mg} / \mathrm{l}$ had a significant effect on the rooting of pecan and increased the color of leaves and root thickness. Also, Bais et al., (2000) who found that NS had positive effect on root formation of Decalepis hamiltonii plants. The present results regarding the stimulative, effect of providing MS rooting medium with SN or STS on investigated rooting measurement, may be attributed to the physiological role of $\mathrm{Ag}^{+}$ion could be played as an anti-ethylene agent (Fjeld and Moe,1985).

Although, the present results regarding the beneficial effect of (STS) is in congeniality with the findings of several investigators on some plant species. Depending upon the function of silver which appears 
unique among the heavy metals acting as an ethylene antagonist (playing as an inhibitor of ethylene biosynthesis) (Beyer, 1976 and Balletti et al., 1994). All suggested that beneficial effect may be attribute to such reason. However, the STS complex was more preferable than the uncomplexed silver ion, may be attributed mainly to the much greater mobility of the formers form (STS complex) in plant tissue than the mineral ion (Veen and Van de Geijn, 1978). The beneficial effects of the ethylene inhibitor STS on organogenesis have been widely reported (Bais et al., 2001; Steinitz et al., 2010 and Reddy et al., 2012). The $\mathrm{Ag}^{+}$ions inhibit ethylene action in a wide variety of ethylene induced response in plants. The ethylene inhibiting effect of $\mathrm{Ag}^{+}$is believed to be due to an interference with ethylene binding (Beyer, 1979). The positive effect of $\mathrm{Ag}^{+}$ions in shoot regeneration suggests that ethylene produced by cultured explants inhibits shoot organogenesis of those explants (Chi et al., 1990).
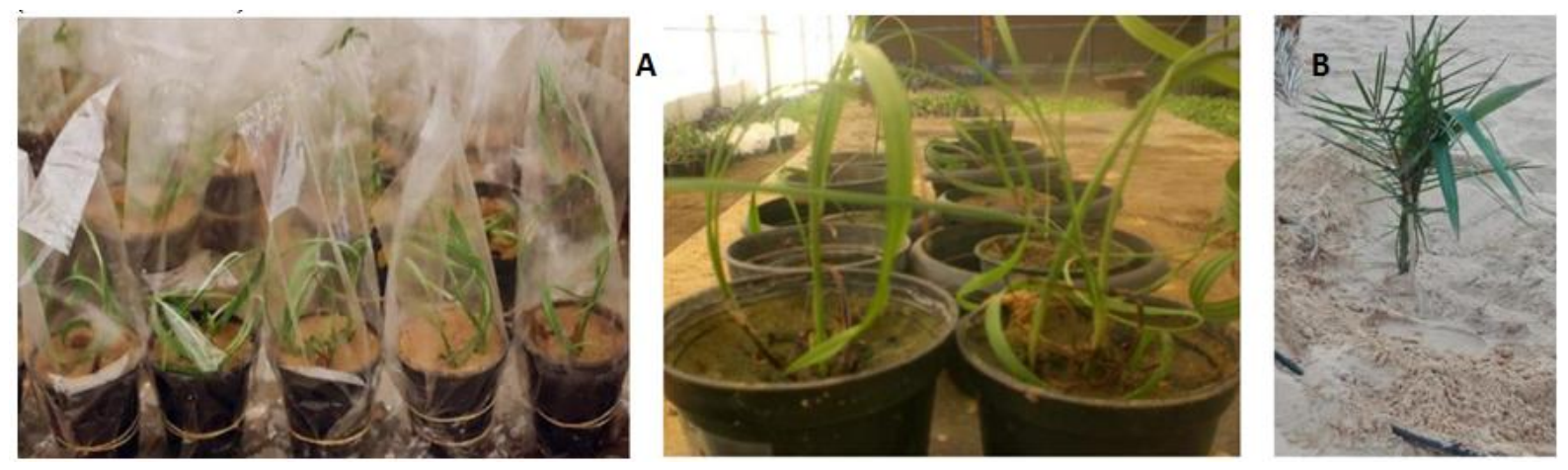

Figure 7: Acclimatization stage of date palm cv. Ghazal. A. Successful acclimatized plantlets in the greenhouse and B. Plantation in the field.

Plantlets resulted from the rooting previous stage were acclimatized and successfully transferred to the greenhouse (Fig. 7A) and transplanted in pots containing a mixture of peat moss and perlite at equal volume then plants were successfully cultured in the field (Fig. 7B). In conclusion, this study has demonstrated the effectiveness of ethylene inhibitor, SN and STS in promoting somatic embryogenesis in date palm. Thus this ethylene antagonist (SN or STS) may be useful as a medium supplement to develop efficient in vitro propagation and rooting protocol so as to conservation this endangered date palm cultivar Ghazal. The development of this effective micropropagation technology will be important step towards its conservation.

\section{References}

[1] Abdellatef, E.; M. Ahmed; H. Daffal and M. Khalafalla (2010). Enhancement of adventitious shoot regeneration in sesame (Sesamum indicum L.) cultivar promo key using ethylene inhibitors. J. Phytol., 2 (1):61-67.

[2] Adkins, S.W.; R. Kunan - uvatchaidach; S.J. Gray and A.L. Adkins (1993). Effect of ethylene and culture environment on rice callus proliferation. J. Exp. Bot., 44:1829-1835.

[3] Akasaka Kennedy, Y.; H. Yoshida and Y. Takahata (2005). Efficient plant regeneration from leaf of rapeseed (Brassica napus L.): the influence of $\mathrm{AgNO}_{3}$ and genotype. Plant Cell Rep., 24:649-654.

[4] Al-Khateeb, A. A.and Ghazzawy, H.S (2015). Influence of polyethylene glycol and gibberellin on somatic embryogenesis of date palm (Phoenix dactylifera L.) cv. Sukkary. Journal of Global. 4(6):2446-2451.

[5] Al-Khayri, J.M. and A.M. Al-Bahrany (2001). Silver nitrate and 2-isopentyladenine promote somatic embryogenesis in date palm (Phoenix dactylifera L.). Scientia Hortic., 89: 291-298.

[6] A Al-Khayr, J.M. and A.M. Al-Bahrany (2004). Genotype dependent in vitro response of date palm (Phoenix dactylifera L.) cultivars to silver nitrate. Scientia Hortic., 99(2): 153-162.

[7] Al-Khayri, J.M. (2011a). Basal salt requirements differ according to culture stage and cultivar in date palm somatic embryogenesis.Ameri. J. Biochem.Biotechnol., 7 (1): 32-42.

[8] Al-Khayri, J.M. (2011b). Influence of yeast extract and casein hydrolysate on callus multiplication and somatic embryogenesis of date palm (Phoenix dactylifera L.). Scientia Hortic., 130:531-535.

[9] Bader, S.M. and H.S.M. Khierallah (2009). The role of silver thiosulfate and glutamine on direct organogenesis of two date palm (Phoenix dactylifera L.) culttivars. Journal of Biotechnology Research Center. 3(1): 37-45.

[10] Bais, H.; G. Sudha, and G. Ravishankar (2001). Influence of putrescine, silver nitrate and polyamine inhibitors on the morphogenetic response in untransformed and transformed tissues of Cichorium intybus and their regenerants. Plant cell Rep., 20 (6): 547-555.

[11] Bais, H.; G. Sudha; B. Sursh and G.A. Ravishankar (2000). $\mathrm{AgNO}_{3}$ influences in vitro root formation in decalepis hamiltonii wight, Arn., Current Sci., 79: 894-898.

[12] Balletti, P.; S. Lanteri; S. Lotito; F. saracco; L. Quagllotti and P. Ballett (1994). Production of potato microtubers through in vitro culture. Acta Hortic., 362: 141-148.

[13] Bekheet, S. (2013). Direct organogenesis of date palm (Phoenix dactylifera L.) for propagation of true - to - type plants. Scientia Agric., 4 (3): 85-92.

[14] Beyer, E.M. (1976): A potent inhibitor of ethylene action in plants. Plant physiol., 58(3): 268-271.

[15] Beyer, E.M. (1979). Effect of silver ion, carbon dioxide, and oxygen on ehylene action and metabolism. Plant Physiol., 63: 169-173.

[16] Bleecker, A.B. and H. Kende (2000). Ethylene: A gaseous signal molecule in plants. Annual Review of Cell and Developmental Biology. 16: 1-18. 
[17] Chi, G.1.; D.G. Barfield; G.E. Sim and E.C. Pua (1990).Effect of $\mathrm{AgNO}_{3}$ and amino ethoxyvinylglycine on in vitro shoot and root organogenesis from seeding explants of recalcitrant Brassica genotypes. Plant Cell Rep., 9:195-198.

[18] Diab, M.I. (2015). In vitro propagation of the endangerd date palm (Phoenix dactylifera L.) cv.Ghazal 1-Effect of Folic Acid and Biotin on callus formation and differentiation. American-Eurasian J. Agric. \& Environ. Sci., 15 (3): 284-290.

[19] Duncan, D.B. (1955). Multiple range and multiple F tests. Biometrics. 11: 1-42.

[20] Fjeld, T. and R. Moe, (1985). Compounds to increase shelf life, specially silver thiosulfate (STS). Grather Tidende, (49): 1380-1583 (C.G. Hort. Abst. 58).

[21] Hassanen, S.A. and M.F. Gabr (2013). In vitro rooting of pecan (Caryca illinoensis Wang -C.Koch).World Applied Sci. Journal. 21(3): 315-319.

[22] Hatanaka, T.; E. Sawabe; T. Azuma; N. Uchida and T. Yasuda (1995). The role of ethylene in somatic embryogenesis from leaf discs of Coffea canephora. Plant Sci. 107, 199-204.

[23] Kumar, P.P.; P. Lakshmanan and T. A. Thorpe (1998). Regulation of morphogenesis in plant tissue culture by ethylene..In vitro Cell Dev. Biol. Plant 34:94-103.

[24] Kumar, V.; G. Parvatam and G.A. Ravishankar (2009). AgNO - a potential regulator of ethylene activity and plant growth modulator. Electronic J. Biotechnology. 12 (2) 1-15.

[25] Kurup, S. S.; M. A. M. Aly; G. Lekshmi and N.H. Tawfik(2014). Rapid in vitro regeneration of date palm (Phoenix dactylifera L.) cv. Kheneizi using tender leaf explant. Emir. J. Food Agric., 26 (6): 539-544.

[26] Liu, X. and P. M. Pijut. (2008).Plant regeneration from in vitro leaves of mature blackcherry (Prunus serotina) Plant Cell Tiss Organ Cult.,94:113-123.

[27] Mele, E; J. Messegwer and P. Camprubi (1982). Effect of ethylene on carnation explants grown in sealed vessels pp.69-70 in Fujiwara (ed.).

[28] Murashige, T. and F. Skoog (1962). A revised medium for rapid growth and bioassays with tobacco tissue cultures. Physiol. Plant., 15:473-497.

[29] Osman, M.G. and M. Khalafalla (2010). Promotion of in vitro shoot formation from shoot tip of tomato (Lycopersicon esculentum Mill. cv. Omdurman) by ethylene inhibitors. Int. J. Curr. Res.,4:82-86.

[30] Panathula, C.S.; M.D. Mahadev and C.V. Naidu (2014).Silver thiosulphate enhance in vitro regeneration of Centella asiatica (L.) An important antijaundice medicinal plant. Int. J. Med. Arom. Plants. 4(2):82-87.

[31] Petri, C. and R. Scorza (2010). Factors affecting adventitious regeneration from in vitro leaf explant of 'improved French' plum, the most important dried plum cultivar in the USA. Ann. Appl. Biol., 156: 79-89.

[32] Pierik, R. L. (1999). in vtiro culture of higher plant. Third edition mortinus nijn of publishers. Netherlands.

[33] Reedy, S.H.; M. Chakravarthi; K.N. Chandrashekara and C.V.Naidu (2012). Infuence of Bavistin and Silver Thiosulphate on in vitro Regeneration of Asclepias curassavica L. Using nodal explants. American J. Plant Sci., 3: 942-946.

[34] Roustan, J.P.; A. Latche and J. Fallot (1990). Control of carrot somatic embryogenesis by $\mathrm{AgNO}_{3}$ an inhibitor of ethylene action: effect on arginine decarboxylase activity. Plant Sci., 67(1): 89-95.

[35] Sandra, A.T. and O. Maira (2013). Effect of culture medium consistence and silver nitrate on micropropagation of two potato (Solanum tuberosum) cultivars. Rev. Colomb. Biotecnol., 15(2):55-62.

[36] Sarropoulou, V.; K. Dimassi- Theriou and L. Therios (2016). Effect of the ethylene inhibitors silver nitrate, silver sulfate, and cobalt chloride on micropropagation and biochemical parameters in the cherry rootstocks CAB-6P and Gisela 6. Turkish J. Biol., 40: 670683.

[37] Snedecor, G.W and W.G. Cochran (1982). Statistical Methods. $7^{\text {th }}$ Ed. Iowa State Univ. Press Ames. Iowa, USA.

[38] Songstad, D.D.; D.R. Duncan and J.M. Widholm (1988). Effect of 1-aminocyclopropane -1-carboxylic acid, silver nitrate and norbornadiene on plant regeneration from maize callus cultures. Plant Cell Rep., 7: 262-265.

[39] Sridhar, T.M.; D. Preethi and C.V. Naidu (2011). Effect of silver thiosulphate on in vitro plant regeneration of Solanum nigrum (Linn.) - An important antiulcer medicinal plant. Current Botany. 2 (7): 14-16.

[40] Steinitz, B.; N. Barr; Y. Tabib; Y. Vaknin and N. Bernstein (2010). Control of in vitro rooting and plant development in Corymbia maculate by silver nitrate, silver thiosulfate and thiosulfate ion. Plant Cell Rep., 29: 1315-1325.

[41] Tamimi, S.M. (2015). Effect of ethylene inhibitors, silver nitrate $\left(\mathrm{AgNO}_{3}\right)$, cobalt chloride $\left(\mathrm{CoCl}_{2}\right)$ and aminooxyacetic acid $(\mathrm{AOA})$, on in vitro shoot induction and rooting of banana (Musa acuminata L.) Afr. J. Biotechnol., 14 (32): 2510-2516.

[42] Veen, H. and S.C. Van de Geijn (1978). Mobility and ionic form of silver as related to longevity of cut cornations. Planta. 140: 9396.

[43] Zhao, J. and L.C. Davis (2005). Verpoorte C Elicitor signal transduction leading to production of plant secondary metabolites. Biotech. Adv., 23: 283-333.

[44] Ziv, M. (1992). The use of growth retardants for the regulation and acclimatization of in vitro plants. In: Karssen, C.M.; L.C. Van Loon and D. Vreugdenhil (eds.) Progress in Plant Growth regulation.pp.809-817.

Mohamed Ismail Diab. "In vitro propagation of the endangered date palm (Phoenix dactylifera L.) cv. Ghazal: 2- Improvement of germination and development of embryos by silver nitrate and silver thiosulfate." IOSR Journal of Biotechnology and Biochemistry (IOSR-JBB) 3.4 (2017): 66-74. 